\title{
EFFECT OF SPRAYING ORGANIC ACID ON YIELD AND FRUIT QUALITY OF "ANNA" APPLE TREES AND ITS EFFECT ON NUTRITIONAL VALUE OF YOGHURT Wafaa Ahmed ${ }^{1}$ and A. Abd El-bary ${ }^{2}$ \\ ${ }^{1}$ Food Tech. Res. Inst.,, Agriculture Research Centre, Cairo, Egypt \\ ${ }^{2}$ Horticulture Research Institute, Agriculture Research Centre, Cairo, Egypt
}

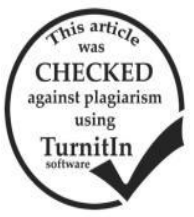

\begin{abstract}
This study was carried out during two successive seasons of 2013 and 2014 in order to study the effect of organic acid as salicylic acid (SA) at 0, 100 and $200 \mathrm{ppm}$ on yield and fruit quality of nine years old "Anna" apple trees(Malus domastica) grown in clay soil. The present goals of the present research were to study the effect of salicylic acid (100, $200 \mathrm{ppm})$ on fruit set ,yield and fruit quality, mainly, the sugar, pectin, acidity and protein contents, compared with untreated apple trees. Flowering fruit set, yield and fruit quality at each $100 \& 200$ improved by using salicylic acid, compared by untreated trees. It could also noticed that salicylic acid at 200ppm enhanced physical (fruit weight, fruit length. Fruit dimension and firmness) and chemical properties (TSS, total acidity, total sugars, pectin and protein).

Milk was fortified with 8 and12\% (w /v ) of apple treated by salicylic acid. The study was to evaluate the chemical, and microbiological qualities of yoghurt variants during storage. The obtained results revealed that total solids (TS), fat, protein and ash contents varied due to variations of manufacturers and type of milk used. The resultant Yoghurt with apple fruit treated by salicylic acid contained an increase of total solids, protein and decreased of acidity and microbiological analysis. Yoghurt also had a good quality for the products.
\end{abstract}

\section{INTRODUCTION}

Salicylic acid is a phenolic phytohormone, it plays an important role in plant growth, and development ,photosynthesis, transpiration, ion uptake and transport (Hayat \& Ahmad 2007). It is also effective in enhancing yield and fruit quality of different fruit crops (Ahmed et al, 2010; Abada and Abd El-Hameed, 2010 and Wassel et al, 2011).

Quercetin" is an antioxidant being found in apple, the presence of which reduces cellular death caused by oxidation and inflammation of neurons. Apples are rich in fibers and vitamins $\mathrm{C}, \mathrm{K}$, vitamins B6, and riboflavin. Apple also characterized with its low calories, and free from fat or cholesterol. "Apples are high in polyphenols, which function as antioxidants. Apples have soluble fiber, such as pectin. This nutrient helps prevent cholesterol from building up in the lining of blood vessels, which in turn helps prevent atherosclerosis and heart disease.

Consumption of dairy products is associated with beneficial health effects beyond their nutritional values. Dairy products have also been served as vehicles for functional food ingredients over the last 20 years due to their phytochemical and probiotics properties. Fermented milk products are of beneficial health effect due to the presence of viable probiotic bacteria that keep the digestive and immune systems functioning well. It is also considered as a good source of protein and nutrients important for bone health. Yoghurt helps in preventing osteoporosis, red inuces the risk of high blood pressure and active cultures helps the gut (Lourens.,2001).

The main objectives of this study was to examin the effect of salicylic acid as an organic acid on flowering, fruit set, yield and fruit quality of "Anna" apple trees. Furthermore, to develop functional yoghurt of acceptable quality based on mixing yoghurt and apple. The chemical, rheological, physical and organoleptic characteristics of apple and the formulated yoghurt were determined.

\section{MATERIALS AND METHODS}

This study was carried out during the two successive seasons of 2013 and 2014 on 9- years' old "Anna" apple trees (Malus domastica) grown in a private orchard at Aga city, dakahlia Governorate. Selected trees were grown in clay soil at $4 \times 4 \mathrm{~m}$ apart; nearly similar in growth vigor and fruiting, free from any visual infections and received regularly the recommended horticultural practices.

This investigation included the following eleven treatments from salicylic acid

1- Control (untreated trees).

2- Spraying salicylic acid at $100 \mathrm{ppm}(0.1 \mathrm{~g}-1 \mathrm{~L})$

3 - Spraying salicylic acid at $200 \mathrm{ppm}(0.2 \mathrm{~g}-1 \mathrm{~L})$

Each treatment was replicated five times, one tree per each. salicylic acid was sprayed three times at the first week of March (growth start setting), May and June. Salicylic acid was dissolved in distilled water and the $\mathrm{pH}$ was adjusted at 6.5 with $\mathrm{NaOH}$. Spraying was done till run off. The control trees were sprayed with tap water. The experiment was arranged in a randomized complete block design. Furthermore, to evaluate the efficiency of the tested treatments on tree fruiting and fruit quality the following measurements were carried out.

1-Total number of flowers at full bloom stage was counted.

2-After month, number of fruits were computed to calculate fruit setting (on May), and before harvests the yield number of fruits were counted to calculate final fruit setting (on June).

3- Yield: - At harvest time (maturity) in both seasons yield of selected trees was determined as $\mathrm{Kg} /$ tree for all treatments.

4- Physical and chemical characteristics of the fruits namely fruit weight $(\mathrm{g}$.$) , fruit volume \left(\mathrm{cm}^{3}\right) \%$, fruit 
dimension(length and diameter $\mathrm{cm}$ ), Firmness $\left(\mathrm{Ib} / \mathrm{Inch}^{2}\right)$, juice \%, T.S.S. \%, total sugars $\%$ protein $\%$ , pectin $\%$ and total acidity $\%$ (as citric acid (A.O.A.C., 2005).

After picking, fresh apple fruits were washed, peeled and cut into very small pieces. Buffalo milk (14.88 \% T.S, $5 \%$ Fat) was obtained from the Dairy Science Department, Faculty of Agriculture, Alex. University, Egypt.

Fresh buffalo milk was used and apple was added as a puree for preparing the following treatments :

A: Yoghurt with $8 \%$ apple (control)

B: Yoghurt with $12 \%$ apple (control)

C: Yoghurt with $8 \%$ apple treated by $100 \mathrm{ppm}$ salsilic acid

D: Yoghurt with $12 \%$ apple treated by $100 \mathrm{ppm}$ salsilic acid
E: Yoghurt with $8 \%$ apple treated by 200ppm salsilic acid

F: Yoghurt with $12 \%$ apple treated by $200 \mathrm{ppm}$ salsilic acid

The yoghurt was manufactured according to the protocol proposed by Tamime and Robinson (1999) with some modification as shown in Fig (1).

Total solids (TS), protein, fat, titratable acidity and $\mathrm{pH}$ values of milk and yoghurt were determined according to the method described by AOAC (2000).

Testing and quantification of total count and yeast \& mold was done according to standard methods for examination dairy products .

Texture profile of PCS was measured as described by Bourne (1982) using an Instron Universal Testing Machine model 1195, Stable Micro System (SMS) Ltd., Godalming, UK,

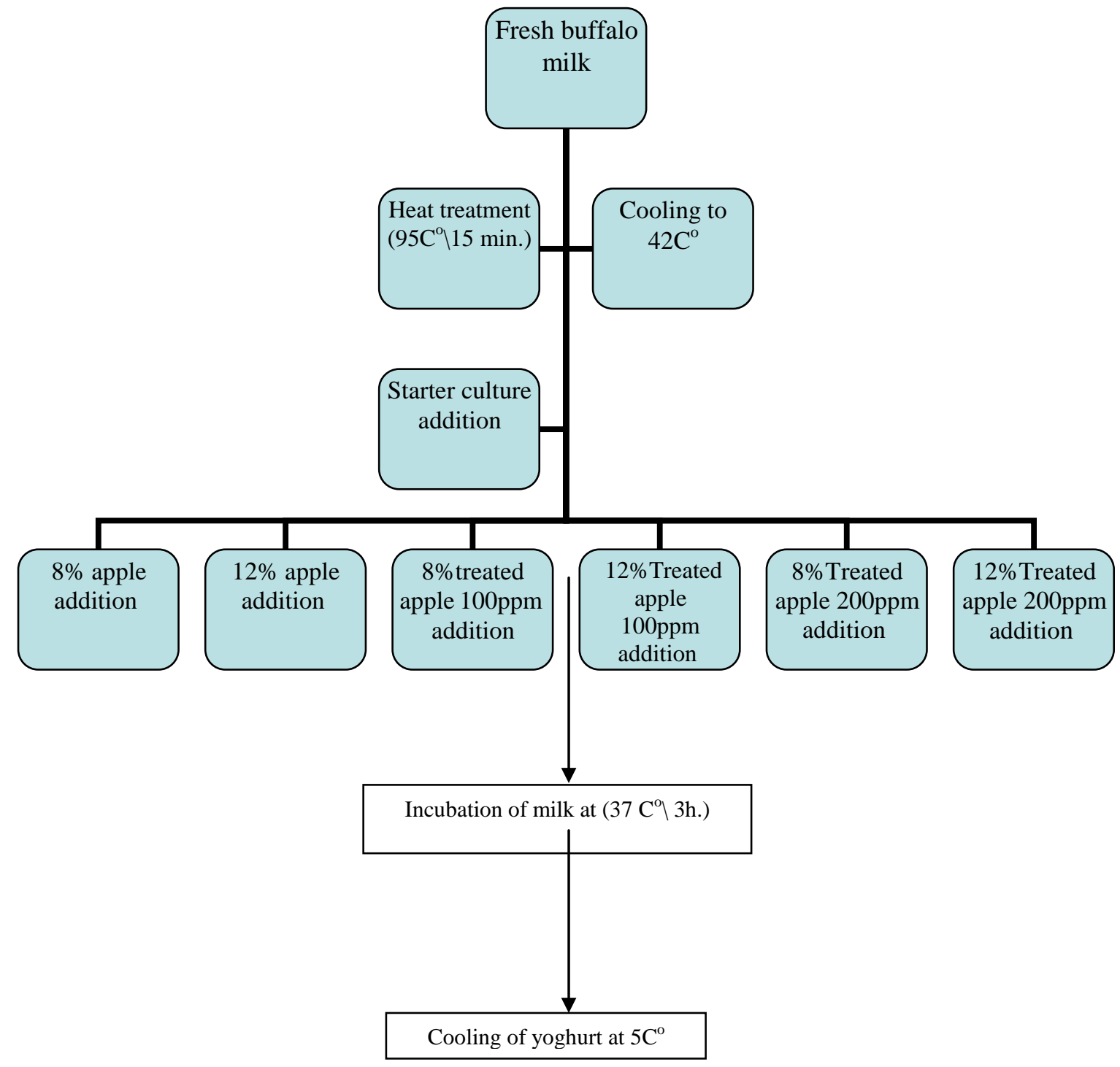

Fig (1) Technological process of yoghurt samples with apple treated by salsilic acid Yoghurt samples were stored for 10 days at $5 C^{0}+0.5 C^{0}$.

Fresh set and flavored yoghurt from the different treatments were evaluated for their sensory attributes by ten well-trained members of the staff of the Food Technology Research Institute. The panelists were judged the samples for appearance(out of 10 points), flavor (out of 50 points) ,Body \&texture (out of 30 points) and color (out of 10 points) as described by ElEtriby et al., (1997). 
Data were statistically analyzed according to the method of Sendecor and Cochran (1990) in each L.S.D at $5 \%$ level for comparison between means of each treatment.

\section{RESULTS AND DISCUSION}

Effect of spraying salicylic acid on flowering, fruit set and yield per tree.

Data in Tables (1) obviously reveal that salicylic acid at 100\&200ppm, significantly improved number of flowers per shoot, percentages of fruit setting and yield rather than non - application. Salicylic acid was significantly very effective in enhancing flowering, fruit setting and yield. Salicylic acid at $200 \mathrm{ppm}$ gave the highest values of flowers number per shoot, fruit set\% and yield $(\mathrm{Kg})$ compared with the lowest concentration during 2013 and 2014 seasons, respectively. Untreated trees produced the minimum number of flowers, fruit set $\%$ and yields during both seasons, respectively.

Flowering is another important parameter that is directly related to yield and productivity of plants. Salicylic acid has been reported to induce flowering in a number of plants (Mahdi et al., 2012). Hayat et al., 2005 reported that salicylic acid application promotes cell division and cell enlargement. According to Shakirova et al. (2003) the positive effect of salicylic acid on growth and yield can be due to its influence on other plant hormones. Salicylic acid altered the auxin, cytokinin and ABA balances in wheat and increased the growth and yield under both normal and saline conditions. Increasing of yield under foliar application of salicylic acid could be ascribed to the well- known roles of salicylic acid on photosynthetic parameters and plant water relations. Fariduddin et al. (2003) reported that exogenous application of salicylic acid enhanced the net photosynthetic rate, internal $\mathrm{CO}_{2}$ concentration and water use efficiency.

Table (1) Effect of spraying salicylic acid on the number of flowers/shoot, percentage of initial fruit set and yield (kg) of Anna apple trees during 2013 and 2014seasons.

\begin{tabular}{lcccccc}
\hline \multirow{2}{*}{ Treatments } & \multicolumn{2}{c}{ No. of flowers /shoot } & \multicolumn{2}{c}{ Initial fruit set \% } & \multicolumn{2}{c}{ yield /tree } \\
& Season 2013 & Season 2014 & Season 2013 & Season 2014 & Season 2013 & Season 2014 \\
\hline Control & $34.0 \mathrm{c}$ & $36.0 \mathrm{c}$ & $26.47 \mathrm{c}$ & $30.00 \mathrm{c}$ & $19.35 \mathrm{c}$ & $22.75 \mathrm{c}$ \\
Salicylic acid at $100 \mathrm{ppm}$ & $44.0 \mathrm{~b}$ & $48.0 \mathrm{~b}$ & $50.00 \mathrm{~b}$ & $55.00 \mathrm{~b}$ & $42.95 \mathrm{~b}$ & $45.15 \mathrm{~b}$ \\
Salicylic acid at 200 ppm & $50.0 \mathrm{a}$ & $55.0 \mathrm{a}$ & $62.00 \mathrm{a}$ & $70.00 \mathrm{a}$ & $49.98 \mathrm{a}$ & $73.12 \mathrm{a}$ \\
\hline
\end{tabular}

Means within each column followed by the same letter(s) are not significantly different at $5 \%$ level

It is clear from the data in Tables ( 2) that spraying salicylic acid, significantly resulted in improving fruit quality in terms of increasing fruit weight $(\mathrm{cm})$, fruit volume $\left(\mathrm{cm}^{3}\right)$ and fruit dimension (cm) but decreasing and fruit firmness $\left(\mathrm{lb} / \mathrm{Inch}^{2}\right)$ in relative to the control treatment. Spraying salicylic acid especially at $200 \mathrm{ppm}$ gave the best results with regard to fruit quality.

A noticeable promotion was observed on fruit quality owing to using salicylic acid Unfavorable effects on fruit quality were observed on untreated trees The effect of salicylic acid on increasing fruit set and promoting productivity of "Anna" apple trees might be attributed to its beneficial effect on reducing reactive oxygen, species that are responsible for destroying plasma membrane as well as enhancing the biosynthesis of IAA and minimizing the unfavorable effects of different stresses on plant development (Senarataa et al, 2004). The promoting effect of different antioxidants on yield and fruit quality was emphasized by the results of Ahmed et al, (2010); Abada and Abd El-Hameed, (2010) and Wassel et al, (2011) on grapevines.

Table (2) Effect of spraying salicylic acid on some physical characteristics of the fruits

\begin{tabular}{|c|c|c|c|c|c|c|c|c|c|c|}
\hline \multirow[t]{2}{*}{ Treatments } & \multicolumn{2}{|c|}{ Weight(g) } & \multicolumn{2}{|c|}{$\operatorname{Size}\left(\mathrm{cm}^{3}\right)$} & \multicolumn{2}{|c|}{ Diameter(cm) } & \multicolumn{2}{|c|}{ Length (cm) } & \multicolumn{2}{|c|}{$\begin{array}{l}\text { Firmness } \\
\left(\text { Ib/Inch }{ }^{2}\right)\end{array}$} \\
\hline & $\begin{array}{c}\text { Season } \\
2013\end{array}$ & $\begin{array}{c}\text { Season } \\
2014\end{array}$ & $\begin{array}{c}\text { Season } \\
2013\end{array}$ & $\begin{array}{c}\text { Season } \\
2014\end{array}$ & $\begin{array}{c}\text { Season } \\
2013\end{array}$ & $\begin{array}{c}\text { Season } \\
2014\end{array}$ & $\begin{array}{c}\text { Season } \\
2013\end{array}$ & $\begin{array}{c}\text { Season } \\
2014\end{array}$ & $\begin{array}{c}\text { Season } \\
2013\end{array}$ & $\begin{array}{c}\text { Season } \\
2014\end{array}$ \\
\hline Control & $129.0 \mathrm{c}$ & $130.0 \mathrm{c}$ & $130.0 \mathrm{c}$ & $132.0 \mathrm{c}$ & $6.0 \mathrm{c}$ & $6.2 \mathrm{c}$ & $6.4 \mathrm{c}$ & $6.9 \mathrm{c}$ & $10.50 \mathrm{a}$ & $11.37 \mathrm{a}$ \\
\hline Salicylic acid at $100 \mathrm{ppm}$ & $156.2 \mathrm{~b}$ & $150.50 \mathrm{~b}$ & $150.0 \mathrm{~b}$ & $130.9 b$ & $6.9 b$ & $7.0 \mathrm{~b}$ & $8.2 b$ & $8.5 b$ & $10.10 \mathrm{~b}$ & $10.10 \mathrm{~b}$ \\
\hline Salicylic acid at $200 \mathrm{ppm}$ & $193.5 \mathrm{a}$ & $195.0 \mathrm{a}$ & $185.0 \mathrm{a}$ & $190.0 \mathrm{a}$ & $7.5 \mathrm{a}$ & $7.5 \mathrm{a}$ & $8.6 \mathrm{a}$ & $8.7 \mathrm{a}$ & $10.10 \mathrm{~b}$ & $10.00 \mathrm{~b}$ \\
\hline
\end{tabular}

Means within each column followed by the same letter(s) are not significantly different at $5 \%$ level

Table (3) shows that apple treated by salicylic acid had a higher T.S.S. \% ,total sugars, proteinand reduced acidity. The sugar content of apples differs depending on the weather conditions, cultivars, culture technology, position and exposition of the fruits in the crown ( Mitre et al., 2009; Sestras et al., 2009). Also, it was noticed that total acidity for fruits registered values between $0.63 \& 0.66$ for trees spraying with $100 \mathrm{ppm}$ and
$0.51 \& 0.55 \%$ for trees spraying with 200ppm respectively during two seasons under study. Low acidity determines a good quality for human consumption. Results in (Table3) illustrated that protein increased in fruits from trees treated by salicylic acid. Chandra et al. (2007) reported that application of salicylic acid increased total soluble sugar and soluble protein of cowpea plants. 
Table (3) effect of spraying salicylic acid on Chemical Composition of Anna apple fruits during 2013 and 2014 seasons

\begin{tabular}{|c|c|c|c|c|c|c|c|c|c|c|}
\hline \multirow[b]{2}{*}{ Treatments } & \multicolumn{2}{|c|}{ Total sugar \% } & \multicolumn{2}{|c|}{ Acidity } & \multicolumn{2}{|c|}{ Pectin \% } & \multicolumn{2}{|c|}{ Protein \% } & \multicolumn{2}{|c|}{ TSS\% } \\
\hline & $\begin{array}{c}\text { Season } \\
2013\end{array}$ & $\begin{array}{c}\text { Season } \\
2014\end{array}$ & $\begin{array}{c}\text { Season } \\
2013\end{array}$ & $\begin{array}{c}\text { Season } \\
2014\end{array}$ & $\begin{array}{c}\text { Season } \\
2013\end{array}$ & $\begin{array}{c}\text { Season } \\
2014\end{array}$ & $\begin{array}{c}\text { Season } \\
2013\end{array}$ & $\begin{array}{c}\text { Season } \\
2014\end{array}$ & $\begin{array}{c}\text { Season } \\
2013\end{array}$ & $\begin{array}{c}\text { Season } \\
2014\end{array}$ \\
\hline Control & $11.02 \mathrm{~b}$ & $11.50 \mathrm{~b}$ & $0.83 \mathrm{a}$ & $0.85 a$ & $0.62 \mathrm{c}$ & $0.66 \mathrm{c}$ & $1.20 \mathrm{c}$ & $1.25 \mathrm{c}$ & 12.5 & $13.0 \mathrm{~b}$ \\
\hline salicylic at $100 \mathrm{ppm}$ & $12.38 \mathrm{a}$ & $12.85 \mathrm{a}$ & $0.63 b$ & $0.66 b$ & $0.73 a$ & $0.77 \mathrm{a}$ & $1.75 b$ & $1.80 \mathrm{~b}$ & 14.5 & $15.0 \mathrm{a}$ \\
\hline salicylic at $200 \mathrm{ppm}$ & $12.94 \mathrm{a}$ & $13.25 \mathrm{a}$ & $0.51 \mathrm{c}$ & $0.55 \mathrm{c}$ & $0.66 \mathrm{~b}$ & $0.69 b$ & $1.86 \mathrm{a}$ & $1.95 \mathrm{a}$ & 14.5 & $15.0 \mathrm{a}$ \\
\hline
\end{tabular}

The changes of composition in different yoghurt as affected by addition of apple treated by salicylic acid were presented in (Table4). The total solids (TS) was higher in yoghurt with apple treated by 100 and 200 ppm of salicylic acid, total solids of control yoghurt was 14.44 and 15.01 while total solids was $14.48,15.08,14.53$ and 15.014 in yoghurt with apple treated by salicylic acid. The nutritional value of yoghurt with apple was better in terms of fat, protein and ash content, these results was due to the composition of apple treated by salicylic acid. The acidity of yoghurt were decreased, it was reported that, the high rate of production of lactic acid in yoghurt was

Table (4) Chemical Composition of Yoghurt

\begin{tabular}{|c|c|c|c|c|c|c|}
\hline Samples & $\begin{array}{c}\text { T.S } \\
\%\end{array}$ & $\begin{array}{c}\text { Protein } \\
\%\end{array}$ & $\begin{array}{c}\text { Fat } \\
\%\end{array}$ & $\begin{array}{c}\text { Ash } \\
\%\end{array}$ & $\begin{array}{c}\text { Titratable } \\
\text { acidity }\end{array}$ & pH \\
\hline $\bar{A}$ & 16.08 & 4.14 & 3.23 & 0.77 & 1.77 & 4.62 \\
\hline B & 16.18 & 4.15 & 3.23 & 0.80 & 1.77 & 4.62 \\
\hline $\mathrm{C}$ & 16.36 & 4.26 & 3.46 & 0.78 & 1.73 & 4.75 \\
\hline D & 16.68 & 4.33 & 3.37 & 0.86 & 1.65 & 4.80 \\
\hline $\mathrm{E}$ & 16.45 & 4.27 & 3.55 & 0.86 & 1.68 & 4.82 \\
\hline $\mathrm{F}$ & 16.77 & 4.34 & 3.69 & 0.88 & 1.60 & 4.89 \\
\hline
\end{tabular}

A: Yoghurt with $8 \%$ apple

B: Yoghurt with $12 \%$ apple

C: Yoghurt with $8 \%$ apple treated by $100 \mathrm{ppm}$ salsilic acid

D: Yoghurt with $12 \%$ apple treated by 100ppm salsilic acid

E: Yoghurt with $8 \%$ apple treated by $200 \mathrm{ppm}$ salsilic acid

F: Yoghurt with $12 \%$ apple treated by $200 \mathrm{ppm}$ salsilic acid

Microbiological analysis of yoghurt with adding apple (Table 5) showed that, total count increased during storage periods, samples A and B had the higher total count than the other treatments. It can be seen clearly from Table 4 that yeast and mold counts increased progressively during storage. Çon et al. ,( 1996 ) found that, the high yeast and mold count observed at the initial 12 days due to the high bacterial metabolic activity with the consumption of lactose (Beal et al.,1999).

In general, the $\mathrm{pH}$ was lower in yoghurts fortified with control apple when compared with apple with salicylic acid. Lee and Lucey (2010) mentioned that, the increased solids content in yoghurt milk as a result of fortification also creates increased buffering that requires additional acid development by starter culture to achieve a similar $\mathrm{pH}$ target .The increasing in $\mathrm{pH}$ values of yoghurt fortified with apple ranged from 4.62 to 4.89 . Ash increased from 0.77 to $0.88 \%$.

Table (5) Microbiological analysis of yoghurt with adding apple

\begin{tabular}{|c|c|c|c|c|c|c|c|c|c|c|c|c|}
\hline Parameters & \multicolumn{2}{|c|}{ A } & \multicolumn{2}{|c|}{ B } & \multicolumn{2}{|c|}{ C } & \multicolumn{2}{|c|}{ D } & \multicolumn{2}{|c|}{$\mathbf{E}$} & \multicolumn{2}{|c|}{$\mathbf{F}$} \\
\hline Storage periods(days) & 5 & 10 & 5 & 10 & 5 & 10 & 5 & 10 & 5 & 10 & 5 & 10 \\
\hline Total count $\left(\log ^{10}\right)$ & 8.18 & 8.48 & 8.20 & 8.52 & 7.31 & 7.44 & 7.32 & 7.42 & 7.13 & 7.20 & 7.06 & 7.12 \\
\hline Molds \&Yeast $\left(\log ^{10}\right)$ & 3.65 & 4.22 & 3.66 & 4.25 & 3.11 & 3.44 & 3.14 & 3.46 & 2.34 & 2.65 & 2.19 & 2.50 \\
\hline
\end{tabular}

Yoghurt made with apple treated by salicylic acid (Table 6), it was observed the differences between treatments of the yogurts fortified with the different dairy ingredients. Results indicated that, except of the springiness criterion, other texture parameters, namely hardness, cohesiveness, gumminess and chewiness

exhibited proportionally higher values. The texture of samples treated by salicylic acid changed, these observation may due to increasing of total solids while, springiness of yoghurt samples behaved opposite trend. Similar findings were reported by Pollard et al.,(2003).

Table (6) Changes in Rheological characteristics of yoghurt with adding apple

\begin{tabular}{|c|c|c|c|c|c|}
\hline Samples & $\begin{array}{c}\text { Hardiness } \\
(\mathbf{N})\end{array}$ & $\begin{array}{c}\text { Chewiness } \\
(\mathbf{N} / \mathbf{m})\end{array}$ & $\begin{array}{c}\text { Cohesiveness } \\
(-)\end{array}$ & $\begin{array}{c}\text { Springiness } \\
(\mathrm{mm})\end{array}$ & $\begin{array}{c}\text { Gumminess } \\
(\mathrm{N})\end{array}$ \\
\hline$\overline{\mathrm{A}}$ & 0.7 & 1.97 & 0.24 & 12.06 & 0.2 \\
\hline B & 0.7 & 1.69 & 0.27 & 12.10 & 0.2 \\
\hline $\mathrm{C}$ & 0.9 & 2.52 & 0.32 & 11.35 & 0.3 \\
\hline $\mathrm{D}$ & 0.9 & 2.55 & 0.38 & 11.15 & 0.4 \\
\hline $\mathrm{E}$ & 1.8 & 3.76 & 0.52 & 11.59 & 0.4 \\
\hline $\mathrm{F}$ & 1.9 & 4.21 & 0.24 & 11.08 & 0.4 \\
\hline
\end{tabular}

N: Newton m: meter mm: millimeter


Sensory attributes were evaluated as flavor, texture, color and overall acceptability. The results for the experimental yogurts are given in (Table 7). The yogurt samples with apple containing salicylic acid had a higher scores of overall acceptability compared with the other treatments. These results may due to the physical characteristics of apple treated by salicylic acid.

Texture of yoghurt is influenced by various factors such as quality and composition of milk and its Table (7) Sensory evaluation of yoghurt with adding apple

\begin{tabular}{|c|c|c|c|c|c|c|}
\hline Sample & $\begin{array}{c}\text { Storage periods } \\
\text { (days) }\end{array}$ & $\begin{array}{c}\text { Appearance } \\
(10)\end{array}$ & $\begin{array}{c}\text { Flavor } \\
(\mathbf{5 0})\end{array}$ & $\begin{array}{c}\text { Body \&Texture } \\
(30)\end{array}$ & $\begin{array}{c}\text { Color } \\
\text { (10) }\end{array}$ & $\begin{array}{c}\text { Overall } \\
\text { acceptability }\end{array}$ \\
\hline \multirow[t]{2}{*}{$\bar{A}$} & 5 & 8 & 46 & 27 & 9 & 90 \\
\hline & 10 & 6 & 42 & 26 & 6 & 80 \\
\hline \multirow[t]{2}{*}{ B } & 5 & 9 & 47 & 27 & 8 & 91 \\
\hline & 10 & 7 & 41 & 25 & 6 & 79 \\
\hline \multirow[t]{2}{*}{$\mathrm{C}$} & 5 & 9 & 47 & 27 & 9 & 92 \\
\hline & 10 & 8 & 44 & 26 & 7 & 85 \\
\hline \multirow[t]{2}{*}{ D } & 5 & 9 & 47 & 27 & 9 & 92 \\
\hline & 10 & 8 & 45 & 27 & 7 & 87 \\
\hline \multirow[t]{2}{*}{$\mathrm{E}$} & 5 & 9 & 48 & 28 & 9 & 94 \\
\hline & 10 & 8 & 46 & 26 & 7 & 87 \\
\hline \multirow[t]{2}{*}{$\mathrm{F}$} & 5 & 9 & 49 & 29 & 8 & 95 \\
\hline & 10 & 8 & 46 & 28 & 7 & 89 \\
\hline
\end{tabular}

\section{CONCLUSION}

Salicylic acid as an organic acid is considered to be a potent plant hormone because of its diverse regulatory roles in plant metabolism. On the other contrary, it could be concluded that salicylic acid at 100 ppm and 200 ppm enhance fruit set, yield and fruit quality of "Anna" apple trees, especially the highest concentration $200 \mathrm{ppm}$.

"Anna" apple fruits treated by salicylic acid as organic acid can be used as a functional ingredient in yoghurt due to its flavor, natural antioxidant, fibers and pectin content in addition to its nutritive constitute and health promoting characteristics . "Anna" apple fruits treated by salicylic acid (as organic acid) improved the rheological characteristics and the total acceptability of yoghurt. Therefore, apple treated by salicylic acid can be used successfully in making functional yoghurt of acceptable sensory attributed comparable with that untreated apple. "Anna" apple fruit treated by salicylic acid as an organic acid at 200 ppm can be recommended in the manufacture of yoghurt with enhanced acceptability comparable to untreated apple samples .

\section{REFERANCES}

Abada, M.A.M. and Abd El- Hameed, H.M. (2010): The beneficial effects of spraying salicylic and citric acids on Flame seedless grapevines. The Sixth Inter. of Sustain Agric. And Develop. Fac. of Agric. Fayoum Univ. 27-29 December pp. 153-164.

Ahmed, F.F.; Abd El- Aziz, F.H. and Abd El- Kariem, A.M. (2010): Relation of fruiting in Crimson seedless grapevines to spraying some antioxidant. Proceeding Minia 2nd Conference of Agric. Environ. Sci. Agric. \& Develop. Scopes. March 2-24 pp. 103- 112. protein and fat content, heat treatment, combination of lactic acid bacteria used, acidification rate, and storage time (Sodini et al., 2004).

Similarly, sensory evaluation scores on the flavor, the body and texture, and the color and appearance of the yogurts fortified with casein hydrolysis decreased by storage time (Zhao et al., 2006). It was observed that, samples $E$ and $F$ had the highest scores of sensory evaluation while, samples A an B had the lowest scores.
A.O.A.C.(2000). Official Methods of Analysis of the Association of the Analytical Chemists. 17ed .

A.O.A.C.(2005). Official Methods of Analysis of the Association of the Analytical Chemists.

Beal, M.F.Mitochondria, N.O. and neurodegeneration. (1999). Biochem. Soc. Symp. 66,43-54.

Bosund, I., I. Erichsen, and N. Molin. "The Bacteriostatic Action of Benzoic and Salicylic Acids.. VI. Influence of Amino Acids and Related Substances on the Growth Inhibition." Physiologia Plantarum 13.4 (1960): 800-11.

Chandra A, Anand A, Dubey A. 2007. Effect of salicylic acid on morphological and biochemical attributes in cowpea. Journal of Environmental Biology, 28: 193-196.

Çon A H, Çakmakcı S, Çağlar A, Gökalp H Y (1996): Effects of different fruits and storage periods on microbiological qualities of fruit-flavored yogurt produced in Turkey. J. Food Prot. 59 :402-406.

El-Etriby, H.M.; El-Darouty, R.T . and Zaghloul, A.H. (1997). Physicochemical and bacteriological studies on mango yoghurt manufacture from ultrafiltrated milk retentat using glucodeltalactone (GDL). Egyptian J. Dairy Sci., 25:349.

Fariduddin Q, Hayat S, Ahmad A. 2003. Salicylic acid influences net photosynthetic rate, carboxylation efficiency, nitrate reductase activity and seed yield in Brassica juncea. Photosynthetica 41: 281-284.

Hayat, S. and Ahmad, A. (2007). Salicylic acid - A Plant Hormone. Springer. ISBN 1-4020-5183-2.

Lee, W. J. and Lucey, J. A. (2010). Formation and physical properties of yoghurt. AsianAustralasian Journal of Animal Science, 23: 1127. 
Lourens, Analie and Bennie C. Viljoen. 2001.Yoghurt as probiotic carrier food, in "International Daiary Journal" No.Vol.11.

Mahdi Javaheri1, Kambiz Mashayekhi, Alireza Dadkhah, Fateme Zaker Tavallaee (2012). Effects of salicylic acid on yield and quality characters of tomato fruit (Lycopersicum esculentumMill.) International Journal of Agriculture and Crop Sciences.Available online at www.ijagcs.com_IJACS/2012/4-16/1184-1187

Mitre, I., V. Mitre, M. Ardelean, R. Sestras and A. Sestras (2009). Evaluation of Old Apple Cultivars Grown in Central Transylvania, Romania. Notulae Botanicae Horti Agrobotanici Cluj-Napoca, 37(1):235-237.

Oliveira, M.N., Sodini, I., Remeuf, F., and Corrieu, G. Effect of milk supplementation and culture composition on acidification, textural properties, and microbiological stability of fermented milks containing probiotic bacteria. Int. Dairy J. 2001; 11: 935-942

Pollard, A., F. Sherkat, M. G. Seuret and A. L. Halmos. 2003. Textural changes of natural cheddar cheese during process. J. Food Sci., 68, 2001-2016.

Senarataa, T.; Touchell, D.; Bunn, E. and Dixon, K. (2004): Acetyle salicylic acid (Aspirin) and salicylic acid induce multiple stress tolerance in bean and tomato plants. Growth Regulator 30:157-161
Sestras, A., R. Sestras, V. Lazar, V. Mitre, I. Mitre, G. Ropan and A. Barbos (2009). The Influence of Fruit Position in the Crown of Trees on the Sugar Content and Morphological Traits of Apple Fruits. Bulletin of University of Agricultural Sciences and Veterinary Medicine Cluj-Napoca. Horticulture 66(1):170-176.

Shakirova F M. 2007. Role of hormonal system in the manisfestation of growth promoting and antistress action of salicylic acid. In: Hayat, S.,Ahmad, A. (Eds). Salicylic Acid. A Plant Hormone. Springer. Dordrecht. Netherlands

Snedecor, G.W. and G.W. Cochran, 1990. Statistical Methods. 7 Ed The Iowa state Univ. Press, Ames, Iowa, USA, pp: 593.

Sodini, I., Remeuf, F., Haddad, S., and Corrieu, G. The relative effect of milk base, starter and process on yoghurt texture: A review. Crit. Rev. Food Sci. Nutr. 2004; 44: 113-137

Tamime, A. Y. and Robinson, R. K. (1999). Yoghurt Science and Technology, London, UK: Woodhead publishing, $598 \mathrm{pp}$.

Wassel, A.M.M.; Ahmed, F.F.; El- Mamlouk,E.A.H. and Fekry W.M.E. (2011): Reliefing clusters looseness and shot berries in Red Roomy grapevines by using some antioxidants. Minia J. of Agric. Res J. develop. Vol. (31): No. 2 pp. 205-217.

Zhao, Q.Z., Wang, J.S., Zhao, M.M., Jiang, Y.M., and Chun, C. Effect of casein hydrolysates on yoghurt fermentation and texture properties during storage. Food Technol. Biotechnol. 2006; 44: 429-434.

\section{تـاثير الرش بحمض عضـوى على المحصول وجـده الثمـار لاثـجار التفـاح "انـا" وتـاثيره على القيمـه الغذائيه

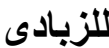

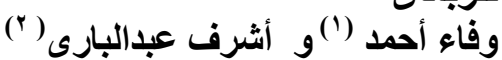 (1)

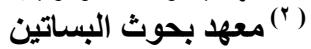

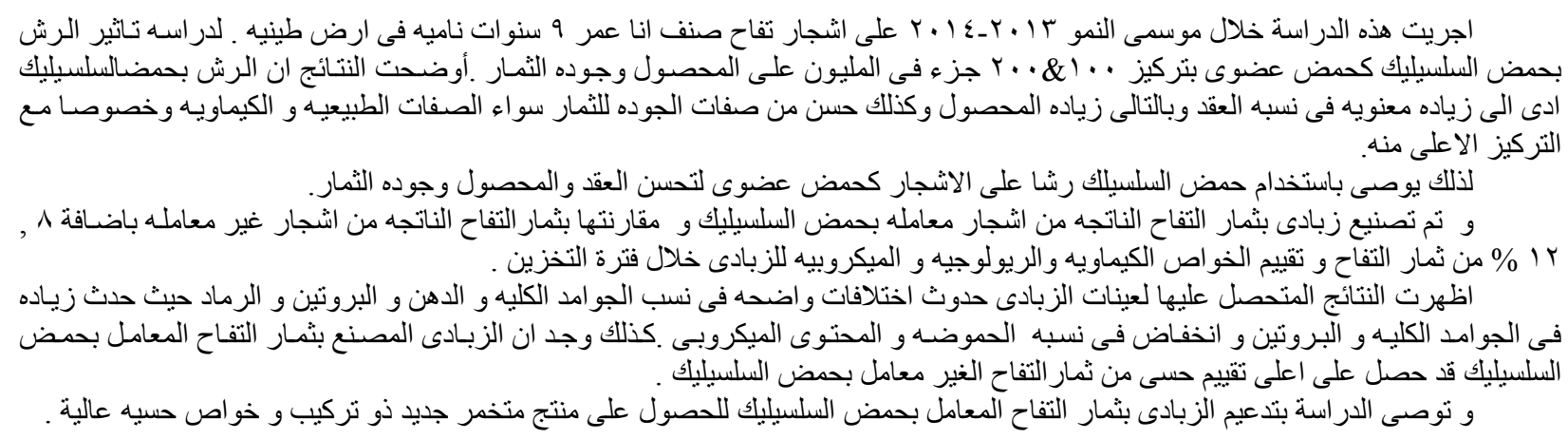

